\title{
Monitoring of Environmental Mercury Exposure Using Hair as Bioindicator and the Study of Potential Factors Affecting on It in Karachi
}

\author{
Nida Ali $^{{ }^{*}}$, Shaikh Mohiuddin', Talat Mahmood ${ }^{2}$, Majid Mumtaz ${ }^{1}$ \\ ${ }^{1}$ Department of Chemistry, University of Karachi, Karachi, Pakistan \\ ${ }^{2}$ Department of Chemistry, Federal Urdu University of Arts, Science and Technology (Gulshan Campus), Karachi, Pakistan \\ Email: "nidaa_07@yahoo.com
}

Received December 1, 2013; revised January 1, 2014; accepted January 16, 2014

Copyright (C) 2014 Nida Ali et al. This is an open access article distributed under the Creative Commons Attribution License, which permits unrestricted use, distribution, and reproduction in any medium, provided the original work is properly cited. In accordance of the Creative Commons Attribution License all Copyrights (C) 2014 are reserved for SCIRP and the owner of the intellectual property Nida Ali et al. All Copyright (C) 2014 are guarded by law and by SCIRP as a guardian.

\section{ABSTRACT}

The World Health Organization (WHO), Environmental Protection Agency (EPA), and International Atomic Energy Agency (IAEA) have recommended the use of hair for worldwide environmental monitoring. Mercury exposure to the inhabitants of Karachi was assessed by using hair as bioindicator. Hair samples of 200 residents of Karachi were collected and analyzed through cold vapor atomic absorption spectroscopy (CVAA) technique for mercury concentration. The effects of age, gender, working status, location, food and smoking habit were investigated. Control region showed a positive correlation between $\mathrm{HHg}$ and age of donor while no such correlation was observed for polluted regions. Mercury exposure through cosmetic usage in female was only pronounced in control region. These results indicate that environmental pollution dominates other potential factors. Age and smoking habit were not found to be the influencing factors while an elevated mean level of mercury was noticed for regular fish consumers than rarely fish consumers. $95.33 \%$ of the samples contained $\mathrm{HHg}$ greater than the permissible level of $2 \mu \mathrm{g} \cdot \mathrm{g}^{-1}$ set by WHO. An apparently healthy male donor had $\mathrm{HHg}$ concentration $\left(28.24 \mu \mathrm{g} \cdot \mathrm{g}^{-1}\right)$ closer to the high risk concentration of $30 \mu \mathrm{g} \cdot \mathrm{g}^{-1}$ based on WHO criteria. Whereas, two female donors of the age group of 41 - 50 years had HHg concentrations $\left(10.82\right.$ and $\left.11.84 \mu \mathrm{g} \cdot \mathrm{g}^{-1}\right)$ higher than the NOAEL (no observed adverse affects level) value $\left(10 \mu \mathrm{g} \cdot \mathrm{g}^{-1}\right)$ for females which is associated with fetus neurotoxicity. However, no symptoms of mercury toxicity were visible. The results indicate the alarming condition of pollution in the city which should be taken into further consideration.

\section{KEYWORDS}

Mercury; Hair; Bioindicator; Cold Vapor Atomic Absorption Spectroscopy (CVAA); Analysis of Variance (ANOVA); Karachi

\section{Introduction}

Human being is the only creature among all who has a supreme expertise of disrupting his environment through pollution of waste and toxic materials. Mercury is one of the highly toxic pollutants because it is a potent neurotoxin to humans [1]. Although mercury occurs naturally in the environment and is widely distributed, environmental mercury level increases through man-made activities such as burning of fossil fuels, industrial pollution,

\footnotetext{
${ }^{*}$ Corresponding author.
}

metal refining, ore processing etc. Along with the atmosphere, sources such as ground-water and pesticides used in agriculture are contaminating the food chain with mercury which ultimately reaches humans $[2,3]$. Biological systems may expose to mercury in the form of liquid mercury, elemental mercury vapors, inorganic mercury salts $\left(\mathrm{Hg}_{2}^{+2}, \mathrm{Hg}^{+2}\right)$ and organic mercury compounds. The toxic effects of mercury depend on its chemical form. Human system cannot absorb a large amount of liquid mercury and it passes through without any toxic effects while mercury vapors may enter into the blood after al- 
veolar absorption. $\mathrm{Hg}(\mathrm{II})$ ion is toxic, however, it is unable to pass through the membrane and cannot enter into the cell. Whereas, $\operatorname{Hg}(\mathrm{I})$ ion is less toxic, but it can enter into the cell and it may oxidize to $\mathrm{Hg}(\mathrm{II})$ in the tissues. Organic mercury is highly toxic because of its nonpolar nature, due to which it is soluble in fats and can spread all over the body by passing through the membrane [4]. Generally, humans get exposed to methyl mercury through fish consumption which can be effectively absorbed by the digestive tract while exposure to mercury vapors $\left(\mathrm{Hg}^{0}\right)$ can be through lungs and skin [2].

The toxic effects of mercury were first realized and well studied when serious mercury poisoning occurred in Japan near the Minamata bay through consumption of fishes and sea foods contaminated with mercury, which was released from an industrial plant into coastal area of Minamata [5]. High affinity for sulfhydryl groups enables both organic and inorganic mercury to destroy every kind of living cell [6]. Brain cell and nerves can be damaged by methyl mercury while inorganic mercury can target endocrine, urogenital and cardiovascular system [2] as it has the ability to cross the blood-brain barrier [1].

Karachi is located at $64^{\circ}$ longitude and $27^{\circ}$ latitude on the shores of the Arabian Sea. This mega city is spread over $3530 \mathrm{~km}^{2}$ with an estimated population of 18 million [7]. Karachi has grown approximately 25 times since 1947, which makes it one of the fastest growing cities of the world [8]. This city is considered to be the hub of commercial and industrial activities of the country. The ever growing population rate and excessive amount of industrial effluents and heavy metals emitting into the air, water and soil $[9,10]$ are responsible for the degradation of the environment. The ultimate victims of the environmental pollution are humans, so it was necessary to assess the mercury exposure to the inhabitants of Karachi.

The World Health Organization (WHO), Environmental Protection Agency (EPA), and International Atomic Energy Agency (IAEA) have recommended the use of hair as an important biological material for worldwide environmental monitoring [11]. Substances, once incorporated into hair, do not have any active metabolism. so unlike short-term indicators (e.g., body fluids) hair provides a valuable medium for long-term information about exposure to toxic element, nutritional status and drug abuse etc. [12]. Human body burden and exposure to mercury can be assessed by measuring the total mercury in hair. The growth rate of human hair is approximately 1 cm per month. Mercury from the blood capillaries incorporates into hair follicles at the time of formation of hair by the process of detoxification. So hair contains a temporal record of exposure to mercury in previous months [2,13]. Moreover, hair can be easily sampled, collected, stored and transported [14] which make it a suitable bioindicator for the assessment of mercury exposure [15].

The present study is the assessment of hair mercury (HHg) concentration in the inhabitants of Karachi by using hair as a bioindicator of environmental mercury exposure.

\section{Material and Methods}

\subsection{Sample Collection}

Hair samples were collected at random from apparently healthy donors of different selected towns of Karachi. The donors included in this study had signed an informed consent about the use of their hair sample prior to sampling. The study was approved by the Ethical Committee of our institution. Sampling sites include the city center and commercial hub of Karachi (Saddar), three main industrial zones of Karachi (Sind industrial Trading Estate-SITE, Landhi and Korangi) and a residential area which is taken as a control environment (Gulshan-e-Iqbal) represented in Figure 1.

An interview-administrated questionnaire containing relevant questions about the donor such as residence location, age, gender, working status (worker or student), smoking and dietary habits (rate of consumption of fish) etc. was used to obtained proper information about each donor. Samples had been taken from the nape of neck of the donors. Total 200 samples (57\% males and 43\% females) have been collected. Each hair sample was placed in a polyethylene bag which is well-labeled with the relevant details about the donor, in order to prevent the mix-up.

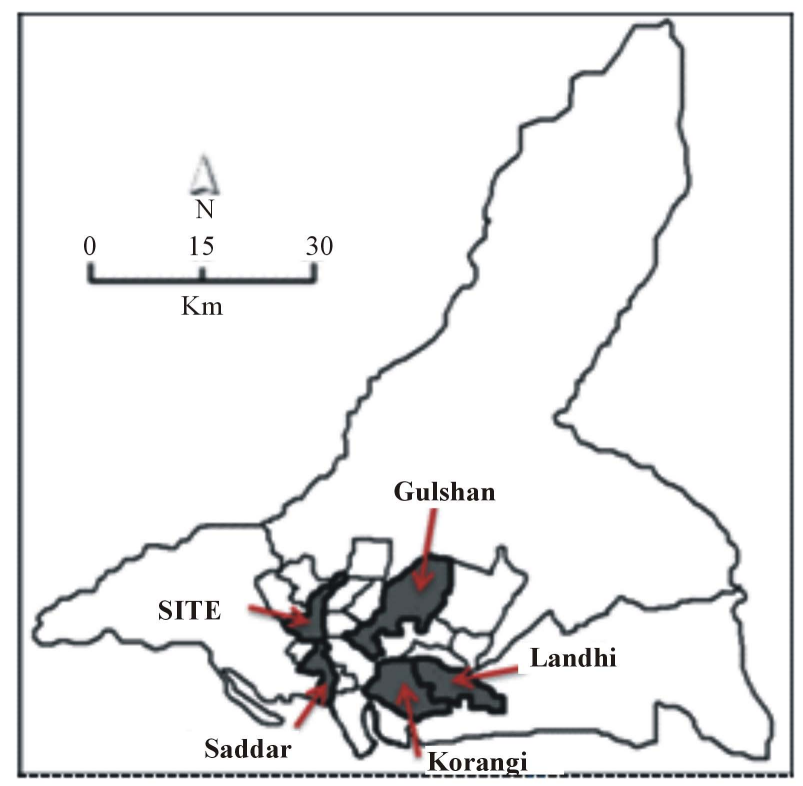

Figure 1. Map of Karachi showing all towns. Selected towns are highlighted and labeled by arrows $(\rightarrow)$. 


\subsection{Sample Preparation and Analysis}

Half of the amount of each hair sample was washed and dried according to [13] for the determination of endogenous mercury level. Washed hair samples were cut into small pieces with scissor, $0.5 \mathrm{~g}$ homogenized hair samples were digested according to [16]. While another half of each sample was digested without washing for the assessment of exogenous mercury level.

Concentration of mercury in the samples was determined by AAS (Perkin Elmer model A Analyst 700) coupled with MHS-15 (Mercury/Hydride) system. The cold vapor technique (CV AAS) was used with $\mathrm{NaBH}_{4}$ as a reducing agent.

\subsection{Statistical Analysis}

Statistical evaluation of the data was performed using a Minitab statistical software mounted on personal computer.

\section{Results and Discussion}

\subsection{Assessment of Regional Effect on HHg Concentration}

HHg levels among selected towns were compared by One-way ANOVA $(\mathrm{p}<0.05)$, that shows significant difference (Figure 2). Mean HHg concentration of the donors of Gulshan was found to be significantly lower than the commercial (Saddar) and industrial (SITE, Landhi, and Korangi) locations.

A statistical comparison by Hsu's MCB (multiple comparisons with the best) was applied; best has chosen to be the smallest of the other. Gulshan is almost a residential town, covers area of $26 \mathrm{~km}^{2}[17,18]$. Gulshan town could be considered as a control in this study because of its better condition of sanitation and garbage dumping, less traffic density and approximately no industrial activities as compared to the other towns. The less polluted environment of this town could be attributed for the lower mercury concentrations in the hair of the donors of this town because of being less exposed to environmental mercury.

Saddar town is a commercial hub of the city, $95 \%$ of its area is used for the commercial uses like huge markets of electronics, cellular phones, jewellery, garments and handicrafts etc. It showed mean $\mathrm{HHg}$ concentration greater than the control environment (Figure 2), the reason could be its compact and densely populated area. Because of being the largest shopping center and wholesale market of the city, high traffic density makes it a congested area. Insufficient sewerage system and garbage dumping, high emission of gases and metallic particles of the exhaust from traffic and residential waste affects the environmental condition of this area $[19,20]$.

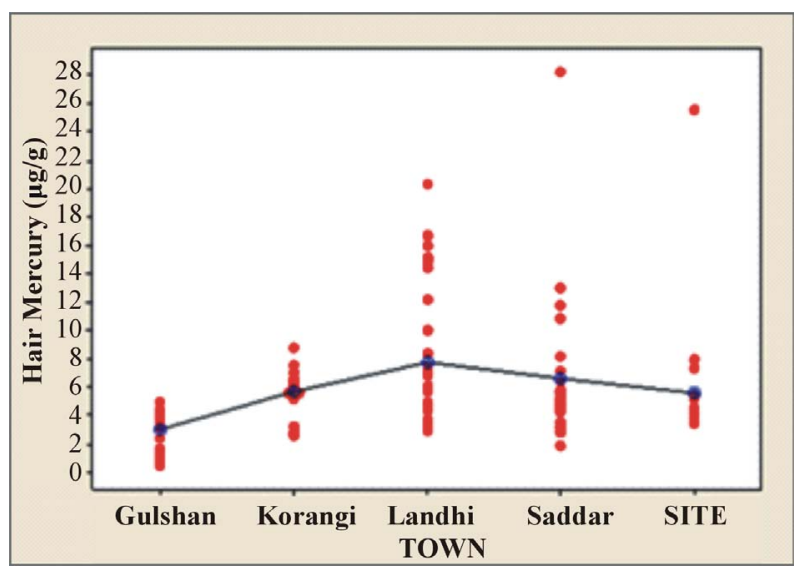

Figure 2. Individual value plot of hair mercury concentrations of the donors of selected towns.

Landhi town showed significantly higher $\mathrm{HHg}$ concentration than the other two industrial towns (Korangi and SITE) (Figure 2). Landhi consists of residential area with low income population, dairy farming, and one of the large industrial zones of Sind Province-LITE (Landhi industrial trading estate). Large quantities of organic matter, oils, greases, heavy metals and other materials are discharge into local rivers [17,21]. The results suggested that peoples in Landhi are more exposed to mercury than the other industrial towns.

Korangi town is near to the coast, along with the residential area it contains various types of industries such as food, pharmaceuticals, oil, textile, garments and tanneries etc. Enormous population and a range of industries make this town polluted throughout the year [20]. The effluents produced by several industries in Korangi are discarded in Malir river, Korangi creek receives industrial effluents from Korangi and Landhi and discharge into Arabian Sea. This causes the contamination of many fishes with high levels of heavy metals (e.g. Hg) in the southeast Arabian Sea [22,23].

Sind Industrial Trading Estate (SITE) is a thickly populated town with approximately 2516 industries. These industries include metal processing, textile, chemicals, pharmaceuticals, flour, dyeing, battery manufacturing, bones crushing, and rubber industries. The industrial waste which is highly polluted with heavy metals and city sewerage is discharged into Lyari River through various channels which are regularly poured into Arabian Sea [24]. The waste effluents discharged from industries and garbage from residential area are considered to be responsible for the degradation of the environment of this area $[10,20]$.

Indus and Hub rivers are the main source of water supply for the inhabitants of Karachi. Other than that, Damloti wells are used for limited supply of water along with the subsurface utilization of water in different parts 
of Karachi. Mercury concentration was found to be higher than the recommended limit by WHO in 100\% drinking water samples collected from Indus, Hub, Damloti well and ground water in Karachi [25]. This could be one of the major sources of mercury exposure to the inhabitants of Karachi.

\subsection{Assessment of Exogenous and Endogenous Mercury Concentration}

Mean mercury concentration in washed samples (containing only endogenous $\mathrm{Hg}$ ) was found to be lower than unwashed samples (containing endogenous and exogenous $\mathrm{Hg}$ ). $\mathrm{Hg}$ and other toxic elements which are poorly handled by renal excretion, get accumulated into hair through blood by the mechanism of detoxification. Hence mercury shows considerable enrichment in hair as compared to blood levels. Human hair consists of approximately $80 \%$ protein, $15 \%$ water and smaller amounts of lipids and inorganic substances [26]. A high proportion of keratin protein in hair consists of cysteine, which is a sulphydryl groups (-SH) containing amino acid [27]. The presence of these sulphydryl groups enables hair to selectively chelate and indefinitely retain heavy metals [26]. Besides blood circulation, other sources of endogenous mercury include sebaceous secretion, exocrine and apocrine sweat [28].

Figure 3 showed the comparison of endogenous and exogenous $\mathrm{Hg}$ level in hair for each town.

Mean endogenous mercury was found to be highest in Landhi town. Reference [25] found that the drinking water from Landhi wells contained 0.33 ppm mercury concentration which is well above the recommended limit of WHO (0.001 ppm). This showed the status of mercury contamination of this town.

The exogenous minerals may also bind to hair through physical and chemical means provided by the fatty secretions of apocrine glands [29]. The migration and accumulation of surface chemicals into hair depends upon the relative permeability of hair epidermis [30]. The probable incorporation of surface contaminant into hair structure could be through the attachment to the -SH groups in hair [27]. Whereas atmospheric pollution, cosmetic treatment, water, external medication and shampoo are the major sources of exogenous mercury [28].

The exogenous mercury level was found to be highest in Saddar town (Figure 3) which represents the most polluted atmospheric environment status of Saddar among all considered towns. Since the use to cosmetics in males is less than females, so the exogenous Hg levels in hair of males could be mainly due to the atmospheric pollution or occupational exposure to mercury. Although females are comparatively less exposed to exogenous mercury through atmospheric pollution because the practice of covering head is generally common in most fe-

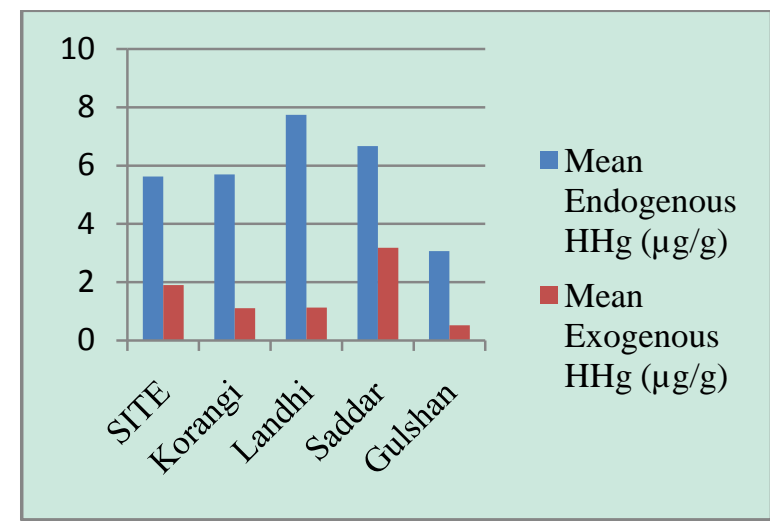

Figure 3. Comparison of endogenous and exogenous hair mercury concentrations among selected towns.

males of Pakistan but the use of cosmetics, shampoos and other hair treatments could increase the risk of exogenous mercury in females.

\subsection{Assessment of Gender Difference Effect on HHg Concentration}

Although the mean mercury concentration in hair of females were found to be slightly higher $\left(5.25 \mu \mathrm{g} \cdot \mathrm{g}^{-1}\right)$ than males $\left(3.52 \mu \mathrm{g} \cdot \mathrm{g}^{-1}\right.$ ) of their respective towns and age groups, but the gender difference in $\mathrm{HHg}$ concentration was only significant for the donors of control environment $(\mathrm{p}<0.5)$. No significant difference in HHg levels for male and female was found for each polluted regions (Saddar, SITE, Korangi and Landhi). This indicates that the effect of gender difference in HHg level cannot be easily observed in the donors which are already under the influence of environmental pollution.

Some previous studies also compared HHg levels in males and females. According to [31], HHg levels in girls were higher than boys. The study results of [13] also suggested that mean concentration of total mercury in scalp hair of females were higher than males.

This could be attributed to the use of mercury containing skin lightening products and other mercurial cosmetics by females. UN reported that blood mercury level is 400 times greater in mercurial cosmetic users than nonusers [32]. According to WHO, mercury is a common ingredient found in skin lightening soaps and creams. It is also found in other cosmetics, such as eye makeup cleansing products and mascara. Skin lightening soaps and creams are commonly used in certain African and Asian countries. Mercury salts inhibit the formation of melanin, resulting in a lighter skin tone [33].

\subsection{Assessment of Working Status Effect on HHg Concentration}

Reference [32] compared total mercury in hairs of students with women associated with different occupations 
the results suggested that working women had average total mercury concentration in scalp hair greater than female students. Results in this study agrees quite well as student's t-test showed that female students contain significantly low $\mathrm{HHg}$ concentration than working females ( $p<0.5$ ) because the use of cosmetics by working females is comparatively greater than female students. While male students also showed less HHg concentration than working males $(\mathrm{p}<0.5)$. This could be attributed for occupational mercury exposure in adults.

\subsection{Assessment of Effect of Age on HHg Concentration}

One way analysis of variance (ANOVA) showed no significant difference $(\mathrm{p}<0.05)$ in $\mathrm{HHg}$ concentration among different age groups. But mercury concentrations of age group of 1 - 10 years were found to be quite less than the other age groups (Figure 4). Children are seemed to be less exposed to pollution, consume less food than other age groups and a little or no cosmetics are used by them, due to which they are comparatively less exposed to mercury.

According to [2], total mercury concentration in hair increases with the age. The same trend is observed only for the donors of Gulshan. Gulshan town showed moderately positive correlation $(r=0.64)$ between $\mathrm{HHg}$ concentration and age of the donors. While no correlation was observed between age and $\mathrm{HHg}$ concentration for the donors of polluted town. This might be due to the impact of environmental pollution which is almost equal on the young children than on the other age groups.

\subsection{Assessment of Fish Consumption Effect on HHg Concentration}

One of the major sources of mercury exposure is considered to be the consumption fish [34,35] as methyl mercury is reported to be the main form of mercury in most fishes [2], which is transform from inorganic mercury by the bacteria in water but the methylation rate varies with the aquatic environment.

The $\mathrm{Hg}^{+2}$ ion forms a covalent compound (methyl mercury) by bonding with methyl anion which is a derivative of vitamin $\mathrm{B}_{12}$ (methylcobalamin), a common constituent of bacteria. Methyl mercury can enter into fish either by direct absorption through water or by accumulation in phytoplanktons, which are then subsequently ingested by noncarnivorous fish. In this way mercury may bioaccumulate into food chain and at each step, the concentration of mercury increases in the organic tissues (biomagnified) because of its affinity for fatty tissues $[4,36]$.

The results suggested that content of mercury in hair depends on the frequency of fish consumption. The mean

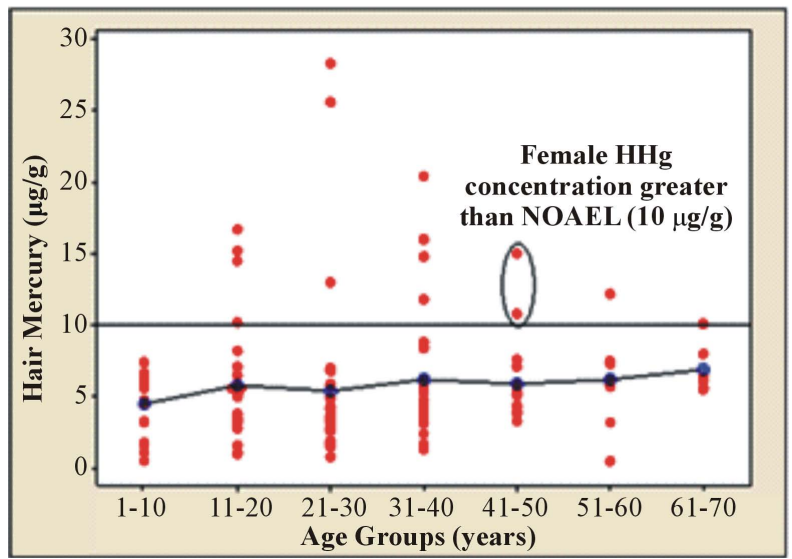

Figure 4. Individual value plot of hair mercury concentrations of different age groups donors.

HHg levels were found to be more for regular fish consumers $\left(18.49 \mu \mathrm{g} \cdot \mathrm{g}^{-1}\right)$ than those who rarely consume fish (4.96 $\mu \mathrm{g} \cdot \mathrm{g}^{-1}$ ). Karachi is located on the northern border of Arabian Sea with $30 \mathrm{~km}$ of coastline of Pakistan. 292 million gallons untreated industrial and municipal waste is being discharged per day from Karachi into the sea through Lyari and Malir rivers. Extremely high level of mercury was found in the coastal water and sea near Karachi. Four types of marine fishes which are commonly consumed by local residents were collected from fish market of Karachi, showed high concentration of mercury [37].

Besides industries and residential pollution of Landhi, its geographical location is also important for consideration, which is near Ibrahim Hyderi and Bin Qasim. Ibrahim Hydery is on the eastern coast of Karachi where fisherman activities are very high, chlor-alkali industries are abundant and an old thermal power plant was in operation here which has abandoned few years ago. While Bin Qasim contains eastern industrial area of Port Qasim, second seaport of country, thermal power plants, steel mill, chemical fertilizer and auto manufacturing plants with thin population [24,17]. The geochemical study of heavy metals in seawater and fish along Karachi-Makran coast conducted by [24] revealed that highest concentration of mercury in seawater and fish was found to be at the coast of Ibrahim Hydery and Bin Qasim. These fishes are exported and are also being extensively used at local scale, this could be the fact of higher HHg concentration found in the residents of Landhi.

\subsection{Assessment of Smoking Habit Effect on HHg Concentration}

Although the mean HHg level in smokers was found to be apparently higher $\left(6.71 \mu \mathrm{g} \cdot \mathrm{g}^{-1}\right)$ than in nonsmokers (4.95 $\mu \mathrm{g} \cdot \mathrm{g}^{-1}$ ) but no significant difference was found statistically. Comparison was made only between those 
smokers and nonsmokers (50\%-50\%) who have same age, location and fish consumption habit so that the influence of other factors can be ignored. These results are in disagreement with that reported by [5], according to whom mean mercury value in smokers was higher as compared to nonsmokers. The outcomes of present study was further confirmed by applying PCA (principal component analysis), which also did not discriminate the HHg content regarding smoking habit (Figure 5).

This suggested that there is no prominent effect of smoking habit on HHg concentration. Pearson correlation coefficient showed very poor correlation between $\mathrm{HHg}$ concentration and age of smokers $(r=-0.125)$.

\section{Conclusions}

Donors of polluted environments are found to be more exposed to mercury than the donors of control environment. The order of endogenous mercury concentration among selected areas was found to be Landhi $>$ Saddar $>$ Korangi $>$ SITE $>$ Gulshan. The results suggested that people in Landhi are more exposed to mercury than the other industrial towns, while exogenous mercury concentration was observed in the order of Saddar $>$ SITE $>$ Landhi $>$ Korangi $>$ Gulshan which represents the most polluted atmospheric environmental status of Saddar among all considered towns.

The use of cosmetics by female increases the level of mercury in their hair than males. Female students contain significantly low $\mathrm{HHg}$ concentration than working females because the use of cosmetics by working females is comparatively greater than female students. Gender difference in HHg concentrations can only be observed for control environment donors who are less influenced by environmental pollution.

The correlation was only observed between HHg concentration and age of the donor of control region while not observed for polluted regions donors. This might be due to the impact of polluted environment which is almost equal on the young children and on the other age groups.

HHg depends on the frequency of fish consumption. Eating fish may increase the level of mercury in the hair. $\mathrm{HHg}$ concentrations of regular fish consumers were found to be significantly higher than rarely fish consumers. No correlation was found between $\mathrm{HHg}$ levels and smoking habit.

95.33\% of the samples of present study contained $\mathrm{HHg}$ concentration greater than the permissible level of 2 $\mu \mathrm{g} \cdot \mathrm{g}^{-1}$ set by WHO [38]. However, the HHg concentrations are all found to be less than NOAEL (no observed adverse affects level) value of $50 \mu \mathrm{g} \cdot \mathrm{g}^{-1}$, suggested by WHO. Although no symptoms of chronic mercury poisoning were observed in donors but a 23-year-old male donor of Saddar town had HHg concentration (28.24

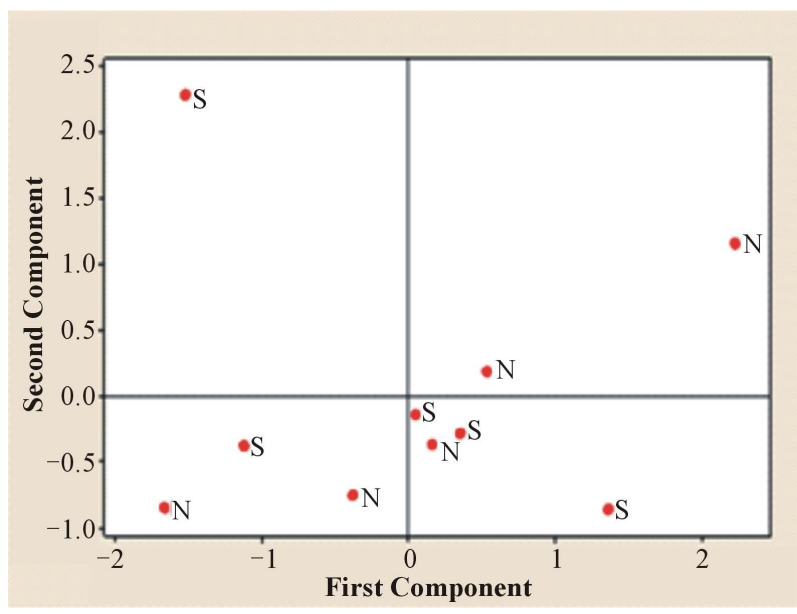

Figure 5. Score plot of hair mercury concentrations in smokers and nonsmokers of selected towns (S = Smokers, $N$ = Nonsmokers).

$\mu \mathrm{g} \cdot \mathrm{g}^{-1}$ ) closer to the high risk concentration of $30 \mu \mathrm{g} \cdot \mathrm{g}^{-1}$ based on WHO criteria [38]. Whereas, two female donors (Figure 4) of the age group of 41 - 50 years had HHg concentrations (10.82 and $11.84 \mu \mathrm{g} \cdot \mathrm{g}^{-1}$ ) higher than the NOAEL value $\left(10 \mu \mathrm{g} \cdot \mathrm{g}^{-1}\right)$ for females, which is associated with fetus neurotoxicity [38]. Mercury may readily pass through the placental barrier, due to which it can pose serious effects on the development of the fetus because the developing brain seems to be three to four times more sensitive than the adult organ [3]. Further studies are needed for monitoring the women at fertile age carefully to prevent potential threats for their fetus.

\section{Acknowledgements}

The authors are grateful to those peoples who had assisted in the sampling and Mr. Azhar Yar Khan for his support in instrumental analysis.

\section{REFERENCES}

[1] V. Mudgal, N. Madaan, A. Mudgal, R. B. Singh and S. Mishra, "Effects of Toxic Metals on Human Health," The Open Nutraceuticals Journal, Vol. 3, No. 1, 2010, pp. 94-99. http://dx.doi.org/10.2174/1876396001003010094

[2] D. Airey, "Mercury in Human Hair Due to Environment and Diet: A Review,” Environmental Health Perspectives, Vol. 52, 1983, pp. 303-316. http://dx.doi.org/10.1289/ehp.8352303

[3] T. W. Clarkson, "Mercury: Major Issues in Environmental Health,” Environmental Health Perspectives, Vol. 100, 1992, pp. 31-38. http://dx.doi.org/10.1289/ehp.9310031

[4] P. K. Bhattacharya, "Metal Ion Toxicity in Biochemical Systems,” In: P. K. Bhattacharya, Ed., Metal Ions in Biochemistry, Narosa Publishing House, New Delhi, 2006, pp. 195-196. 
[5] S. A. Karabedian, F. J. M. Al-Imrah and H. K. Ibraheem, "Determination of Mercury in Hair Samples of Iraqis Population Living in Safwan and Al-Zubair Southern Basrah,” Journal of Duhok University, Vol. 12, No. 1, 2009, pp. 23-27.

[6] T. W. Clarkson, J. Crispin-Smith, O. Marsh and M. D. Trrner, "A Review of Dose-Response Relationships Resulting from Human Exposure to Methyl Mercury Compound,” In: P. A. Krenkel, Ed., Heavy Metals in the Aquatic Environment, Pergamon Press, New York, 1975, pp. 1-12. http://dx.doi.org/10.1016/B978-0-08-018068-7.500 $\underline{05-8}$

[7] City District Government Karachi (CDGK), "Official Web Portal of City District Government Karachi,” 2012. http://14.192.147.139/cdgk/Home/Towns/tabid/72/Defaul t.aspx

[8] S. Qureshi, "The Fast Growing Megacity Karachi as a Frontier of Environmental Challenges: Urbanization and Contemporary Urbanism Issues," Journal of Geography and Regional Planning, Vol. 3, No. 11, 2010, pp. 306321.

[9] S. Atiq-ur-Rehman and M. Z. Iqbal, "Growth of Leucaena Leucocephala (Lam.) De-Wit, in Different Soils of Korangi and Landhi Industrial Areas of Karachi, Pakistan,” Pakistan Journal of Botany, Vol. 39, No. 5, 2007, pp. 1701-1715.

[10] M. Kabir, M. Z. Iqbal, Z. R. Farooqi and M. Shafiq, "Vegetation Pattern and Soil Characteristics of the Polluted Industrial Area of Karachi," Pakistan Journal of Botany, Vol. 42, No. 1, 2010, pp. 661-678.

[11] G. Samanta, R. Sharma, T. Roychowdhury and D. Chakraborti, "Arsenic and Other Elements in Hair, Nails, and Skin-Scales of Arsenic Victims in West Bengal, India," Science of the Total Environment, Vol. 326, No. 1-3, 2004, pp. 33-47. http://dx.doi.org/10.1016/j.scitotenv.2003.12.006

[12] J. A. Hubbart, "Hair Analysis as an Environmental Health Bioindicator: A Case-Study Using Pelage of the California Ground Squirrel (Spermophilus beecheyi),” International Journal of Applied Science and Technology, Vol. 2, No. 3, 2012, pp. 277-294.

[13] E. T. Anim, E. S. Agorku and A. K. Anim, “A Comparative Analysis on Levels of Mercury in Human Scalp Hair of Students from Different Locations in Ghana," Research Journal of Environmental and Earth Sciences, Vol. 3, No. 3, 2011, pp. 293-296.

[14] J. L. Rodrigues, B. L. Batista, J. A. Nunes, C. J. S. Passos and F. Barbosa, "Evaluation of the Use of Human Hair for Biomonitoring the Deficiency of Essential and Exposure to Toxic Elements," Science of the Total Environment, Vol. 405, No. 1-3, 2008, pp. 370-376. http://dx.doi.org/10.1016/j.scitotenv.2008.06.002

[15] P. Montuori, E. Jover, A. Pagano, J. M. Bayona and M. Triassi, "Improvements on a Total Mercury Determination Method in Human Hair Using Graphite-Furnace Atomic Absorption Spectrophotometry Detection," Journal of Preventive Medicine and Hygiene, Vol. 48, No. 2, 2007, pp. 43-46.

[16] H. Akagi, E. S. Castillo, N. Cortes-Maramba, A. T. Fran-
cisco-Rivera and T. D. Timbang, "Health Assessment for Mercury Exposure among Schoolchildren Residing near a Gold Processing and Refining Plant in Apokon, Tagum, Davao del Norte, Philippines," Science of the Total Environment, Vol. 259, No. 1-3, 2000, pp. 31-43. http://dx.doi.org/10.1016/S0048-9697(00)00547-7

[17] A. Siddique, N. A. Zaigham, S. Mohiuddin, M. Mumtaz, S. Saied and K. A. Mallick, "Risk Zone Mapping of Lead Pollution in Urban Groundwater," Journal of Basic and Applied Sciences, Vol. 8, No. 1, 2012, pp. 91-96. http://dx.doi.org/10.6000/1927-5129.2012.08.01.15

[18] A. Zubair and S. N. Siddiqui, "Status of Noise Pollution-A Case Study of Gulshan-E-Iqbal Town, Karachi," Indus Journal of Management and Social Science, Vol. 5, No. 2, 2011, pp.100-105.

[19] A. P. Azad and R. Ahmed, "A Geographical Study of Land-Use in the Commercial Heart of Karachi (Saddar)," Pakistan Geographical Review, Vol. 61, No. 2, 2006, pp. 64-82.

[20] T. A. Rao, A. H. Shaikh and M. Ahmed, “Airborne Fungal Flora of Karachi, Pakistan,” Pakistan Journal of Botany, Vol. 41, No. 3, 2009, pp. 1421-1428.

[21] M. A. Khan, "Problems and Prospects of Urban Environmental Management in Pakistan,” The Pakistan Development Review, Vol. 35, No. 4, 1996, pp. 507-523.

[22] M. Z. Chaudhary, N. Ahmad, A. Mashiatullah, N. Ahmad, T. Javed, M. S. Khan and R. M. Qureshi, "Elemental Depth Profile in Sediment Core of Korangi Creek along Karachi Coast, Pakistan,” The Nucleus, Vol. 49, No. 1, 2012, pp. 39-48.

[23] M. S. Saif, Midrar-ul-Haq and K. S. Memon, "Heavy Metals Contamination through Industrial Effluent to Irrigation Water and Soil in Korangi Area of Karachi (Pakistan)," International Journal of Agriculture and Biology, Vol.7, No. 4, 2005, pp. 646-648.

[24] M. Mumtaz, "Geochemical Studies of Heavy Metals in the Seawater along Karachi-Makran Coast,” Ph.D. Thesis, University of Karachi, Karachi, 2002.

[25] Y. Nergis, M. Sharif and W. Ahmed, "Potable Water as a Source of Heavy Metals in the Blood of Neuro Patients of Karachi, Pakistan," Journal of Chemical Society of Pakistan, Vol. 29, No. 1, 2007, pp. 86-93.

[26] Biolab Medical Unit, “Hair Mineral Analysis,” 2012. http://www.biolab.co.uk/docs/Hair_Mineral_Analysis.pdf

[27] I. C. Nnorom, J. C. Igwe and J. C. Ejimone, "Multielement Analyses of Human Scalp Hair Samples from Three Distant Towns in Southeastern Nigeria," African Journal of Biotechnology, Vol. 4, No. 10, 2005, pp. 1124-1127.

[28] I. F. Rivai, "Heavy Metals in Human Hair Related to Age Groups and Automotive Pollution Levels of Bandarlampung city, Indonesia," Bulletin of Environmental Contamination and Toxicology, Vol. 66, No. 4, 2001, pp. 443448. http://dx.doi.org/10.6000/1927-5129.2012.08.01.15

[29] D. K. Combs, R. D. Goodrich and J. C. Meiske, "Mineral Concentrations in Hair as Indicators of Mineral Status: A Review,” Journal of Animal Science, Vol. 54, No. 2, 1982, pp. 391-398.

[30] R. Pereira, R. Ribeiro and F. Goncalves, "Scalp Hair 
Analysis as a Tool in Assessing Human Exposure to Heavy Metals (S. Domingos Mine, Portugal)," Science of the Total Environment, Vol. 327, No. 1-3, 2004, pp. 8192. http://dx.doi.org/10.1016/j.scitotenv.2004.01.017

[31] J. Batista, M. Schuhmacher, J. L. Domingo and J. Corbella, "Mercury in Hair for a Child Population from Tarragona Province, Spain,” Science of the Total Environment, Vol. 193, No. 2, 1996, pp. 143-148. http://dx.doi.org/10.1016/S0048-9697(96)05340-5

[32] C. P. Kinabo, “Comparative Analysis of Mercury Content in Human Hair and Cosmetic Products Used in Dar es Salaam, Tanzania,” Tanzania Journal of Science, Vol. 31, No. 1, 2005, pp. 83-90.

[33] World Health Organization (WHO), "Mercury in Skin Lightening Products,” 2012.

http://www.who.int/ipcs/assessment/public_health/mercur $\mathrm{y}$ flyer

[34] D. Airey, “Total Mercury Concentrations in Human Hair from 13 Countries in Relation to Fish Consumption and Location," Science of the Total Environment, Vol. 31, No. 2, 1983, pp. 157-180. http://dx.doi.org/10.1016/0048-9697(83)90067-0
[35] K. Kruzikova, H. Modra, R. Kensova, B. Skocovska, T. Wlasow, T. Svoboda and Z. Svobodova, "Mercury in Human Hair as an Indicator of the Fish Consumption," Neuro Endocrinology Letter, Vol. 29, No. 5, 2008, pp. 675-679.

[36] R. Lutter and E. Irwin, "Mercury in the Environment: A Volatile Problem,” Environment, Vol. 44, No. 9, 2002, pp. 24-40. http://dx.doi.org/10.1080/00139157.2002.1054356 1

[37] A. Q. Shah, T. G. Kazi, J. A. Baig, H. I. Afridi, G. A. Kandhro, S. Khan, N. F. Kolachi and S. K. Wadhwa, "Determination of Total Mercury in Muscle Tissues of Marine Fish Species by Ultrasonic Assisted Extraction Followed by Cold Vapor Atomic Absorption Spectrometry," Pakistan Journal of Analytical and Environmental Chemistry, Vol. 11, No. 2, 2010, pp. 12-17.

[38] T. Agusa, T. Kunito, H. Iwata, I. Monirith, T. S. Tana, A. Subramanian and T. Tanabe, "Mercury Contamination in Human Hair and Fish from Cambodia: Levels, Specific Accumulation and Risk Assessment,” Environmental Pollution, Vol. 134, No. 1, 2005, pp. 79-86. http://dx.doi.org/10.1016/i.envpol.2004.07.015 